\title{
研究課題別事後評価結果
}

1. 研究課題名：X線1分子計測からのin-Vivo蛋白質動的構造／機能解析

2. 研究代表者名及び主たる研究参加者名 (研究機関名・職名は研究参加期間終了時点)

研究代表者

佐々木 裕次 (SPring-8/(財)高輝度光科学研究センター 主幹研究員)

主たる共同研究者

老木 成稔 (福井大学医学部 教授) (平成 13 年12月～)

岡本 祐幸 (名古屋大学大学院理学研究科 教授) (平成 13 年 12 月～)

3. 研究内容及び成果:

研究全体概要:

蛋白質分子の動的構造情報/機能相関を詳細に解析するには、原子レベル以下の精度でin Vivo動的1分子 構造情報が安定に得られ、同時に1分子機能計測も併用可能なX線1分子計測法が最も有効である。本法を膜 蛋白質分子のin vivo計測へ適用し、また本法と計算科学を合体させた全く新しい蛋白質構造決定法を検討す る。

実施内容及び成果:

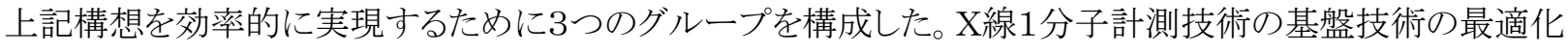
及び高度化を主に担当する佐々木グループ。また、構造変化と機能評価の同時計測を実現するために、極め て注目されているKチャネル膜タンパク質分子KcsAを研究対象とし、この機能性膜タンパク質分子に関する構 造変化計測以外の研究を含めて老木グループが担当した。そして1分子運動の理論的な裏付けを研究するた めに岡本グループが加わった。

佐々木グループは、放射光を用いた実験をするだけでなく、本計測法の重要プローブであるナノ結晶の完全 結晶化技術を軸としてその周辺技術に関する研究開発を進めた。結晶化技術は可視領域1分子計測法にも応 用展開が可能な技術開発である。タンパク質 1 分子計測を実現するための基幹技術である分子配向技術構築 にも時間を要した。1分子運動計測を行った生体分子系は数多くあり、光励起型の構造変化で知られている膜 タンパク質分子からフィラメント分子まで多くの形状及び分子量の計測を試みた。それらの計測結果から本計測 法の高精度性の証明、新規な分子配向技術の確立、超微小なX線放射圧の計測及びその応用、抗原抗体反 応の高感度計測法の提案等が行われた。特にX線放射圧に関しては研究計画当初全く考慮されていなかった 現象であり、想定外の成果である。加えて抗原抗体反応の1分子検出の可能性を示寸ことができ、本計測手段 の医療診断等への実践的応用への展開が期待される。放射光を用いた計測装置開発においては、測定の自 動化、解析ソフトの開発、ナノ結晶評価技術の確立、また広波長領域X線利用と準単色X線利用の場合の基盤 技術を確立した。加えてX線1分子計測法の原理を応用した電子顕微鏡に関する研究は、プロジェクトの後半に その基礎検討を開始し、成果を得る事ができた。小型放射光施設の利用も多角的に検討されたが、本計測手 段の装置小型化は電子顕微鏡利用がその回答であると結論づけた。

老木グループでは、X線1分子計測を利用することで必要となった生体分子へのシステイン残基導入を主に 行い、その過程で新しい構造評価法やKチャネル膜タンパク質分子の新たな特性に関する研究へと展開させる ことができた。最終的なゴールは、チャネルの開閉時における構造変化計測とそれに同期した機能計測の実現 であったが、より信頼できる分子内運動計測を成し遂げるために、KcsA分子を基板表面に配向させ、チャネル 
開閉状態を水溶液のpH条件を変化させることで制御し、多くの変異体を用いて動的 1 分子構造変化測定を多 角的に計測し解析することに集中した。既知の膜貫通領域の立体構造によって予想された細胞内ドメイン構造 を基に、上記変異体を用いて様々な位置に金ナノ結晶を結合させる実験から、反応可能な表面露出性をスクリ ーニングするための表面プラズモン共鳴法を用いた新しい構造解析法も提案した。この方法により、タンパク質 分子の詳細な構造情報が分からなくても表面活性部位がどの位置にあるかを検討することが可能となった。この ような最適な金結晶標識位置をもとめるスクリーニング実験に平行して、変異したチャネル機能を脂質平面膜法 の一種であるtip-dip法によって単一チャネル電流記録も行った。この過程でチャネルゲート機構に関するまった く新しい機構を発見することもできた。これらの結果は、同時測定の前座の研究として位置づけられるが、多くの 新しい事実が明らかになった。最終的に、KcsA分子自身の本来ある生体膜内での並進運動を除外し、運動の 解釈を正確に行うことで、チャネル開閉に伴う予想外の分子内構造変化を検出することに成功した。検出された 分子内運動は予想を超え極めて大きな運動であり、かつ複雑であることが本実験で初めて明らかとなった。膜夕 ンパク質分子の機能発現に伴う分子内実時間運動計測の一歩となった。

岡本グループは、近年多くのX線以外の可視光を用いた1分子計測法が盛んに行われている中で、計測され ている現象を理論的に解釈することが平行して進められている訳ではないといら現状に注目し、生体分子の構 造予測を中心に研究を行ってきた。X線1分子計測の基本は、生体分子を基板に配向し、ナノ結晶を標識する といら一見生体分子にとってはかなり過酷な運動条件となっている。これがどの程度運動を抑制しているか定量 的な検討が必要であった。無論実際の実験においてもこれらの検証は、ナノ結晶の大きさを制御し、配向スペ 一スの制御することで実際の実験でも検証可能で、佐々木グループの協力で行うことができた。理論ではかなり の位置精度が達成されるし、X線1分子計測も1分子計測技術の中では最高精度を誇る。結果的に本計測の測 定条件化での分子内運動計測を行うことで、分子自身の運動を大きく変調させる現象はないと結論した。

本研究を通して得られた知見の代表例9点を、その成果を報告した論文とともに記す。

(1)ナノ結晶を標識することで生体高分子内部の構造変化実時間計測が可能であることを世界で初めて示し た。

(2)多くの生体高分子を含む高分子の実時間構造摇らぎ計測から予想より“硬い構造“摇らぎを実測した。

Y. C. Sasaki: Single protein molecular dynamics determined with ultra-high precision, Biochemical Society

Transactions Volume 32, part 5, 761-763(2004)

(3)チャネル開閉時における分子内運動が想像以上に大きい分子全体に渡る回転運動であることを同定した。

H. Shimizu, M. Iwamoto, F. Inoue, T. Konno, Y.C. Sasaki, S. Oiki: Rotary Movements of the pH-sensitive gate of the KcsA channel revealed by Diffraction X-ray Tracking. submitted.

(4) 計測されたチャネルの運動が大きいことから新しい分子運動制御の可能性を示唆した。

(5)表面プラズモン法を用いれば構造の明確でない生体分子系においても分子表層部位の位置を決定するこ とができる。

M. Iwamoto, H. Shimizu, F. Inoue, T. Konno, Y.C. Sasaki, S. Oiki: Surface accessibility of the cytoplasmic domain of KcsA channel evaluated by surface plasmon resonance signal. J. Biol. Chem. 281(38) 28379-28386 (2006).

(6)X線の放射圧による生体分子にかかる圧力を1分子内のブラウン運動を詳細に解析することで同定した。 Y. C. Sasaki, T. Higurashi, T. Miyazaki, Y.Okumura, N. Oishi: Measurements of X-ray Radiation Pressure Force on Single Gold Nanocrystals, Applied Physics Letters, 89, 053121 (2006).

(7) 抗原高抗体反応を1分子レベルで確認する定量的物理因子を確認した。

T.Sagawa, T.Azuma, Y. C. Sasaki: Quantification of protein-ligand bindings from structural fluctuations of single molecules. Science submitted. 
(8) 光活性膜タンパク質分子の分子内運動より本法がオングストローム以下の運動も検出可能と結論した。 Y. Okumura, T. Oka, M. Kataoka, Y. Taniguchi, Y. C. Sasaki: Picometer-Scale Dynamical Observations of Individual Membrane Proteins: the case of Bacteriorhodopsin, Phys. Rev. E, 70, 021917-1-7 (2004).

(9) 1分子理論計算により基板固定やナノ結晶の標識が分子内運動を極端に変調させることはないと結論した。 Y. Kawashima, Y.C. Sasaki, Y. Sugita, T. Yoda, Y. Okamoto "Replica-exchange molecular dynamics simulation of diffracted X-ray tracking” Molecular Simulation (2007), in press.

\section{4. 事後評価結果：}

4-1. 外部発表(論文、口頭発表等)、特許、研究を通じての新たな知見の取得等の研究成果の状況：

論文発表、国内: 2 件、海外:48件。口頭発表、国内: 53 件、海外: 36 件。特許出願、国内: 2 件、海外:0件。

（尚、H19年3月末見込み分を含む）

成果のいくつかが未発表であり、特許とともに今後、さらに増えていくものと期待している。また、本研究内容は、 新たにCRESTの研究課題しして採択され、今後も研究が継続して行われるので、更なる発展を期待したい。

$4-2$. 成果の戦略目標・科学技術への貢献:

本研究の成果により以下のような科学技術への貢献があった。(1)X線回折現象から1分子内部の回転運動 の情報を安定に高精度に取り出せることを世界で初めて提案した。(2)この方法論を大型施設ではなく電子顕 微鏡を用いても可能であることを示した。(3) 本研究の方法論はナノ結晶を標識する計測技術が主であるがX線 放射圧の計測成功で目的生体分子にナノ結晶を標識せずとも(ハンラベル技術) 生体分子のダイナミクスが計測 できる可能性を示した。

4-3. その他の特記事項(受賞歴など)：

国外からの評価の一端として、本研究の成果により2007年に米国にて開かれるGordon Research

Conferences(X-ray Physics)における招待講演の依頼を受けている。人材育成として、参加した研究者が九州 大学理学研究科助教授へ就任した点と、難関のヒューマンフロンテアサイエンスプログラムに採用されウインスコ シン大学に留学した研究員、海外若手賞を受賞した研究員が出た。 